\title{
The papacy, inquisition and Saint Guinefort the Holy Greyhound
}

Article

Accepted Version

Rist, R. (2019) The papacy, inquisition and Saint Guinefort the Holy Greyhound. Reinardus. Yearbook of the International Reynard Society, 30 (1). pp. 190-211. ISSN 0925-4757 doi: https://doi.org/10.1075/rein.00020.ris Available at https://centaur.reading.ac.uk/81816/

It is advisable to refer to the publisher's version if you intend to cite from the work. See Guidance on citing.

Published version at: https://benjamins.com/catalog/rein.30

To link to this article DOI: http://dx.doi.org/10.1075/rein.00020.ris

Publisher: John Benjamins Publishing Company

All outputs in CentAUR are protected by Intellectual Property Rights law, including copyright law. Copyright and IPR is retained by the creators or other copyright holders. Terms and conditions for use of this material are defined in the End User Agreement.

\section{www.reading.ac.uk/centaur}

\section{CentAUR}

Central Archive at the University of Reading

Reading's research outputs online 


\section{The Papacy, Inquisition and Saint Guinefort the Holy Greyhound \\ Dr. Rebecca Rist, University of Reading}

In April 1988 the New York Times published a review of Suzanne Schiffman and Paméla Berger's 1987 film Sorceress (French version Le Moine et la Sorcière), which debued at the $68^{\text {th }}$ Street Playhouse. It described it as "a parable about the clash between a dedicated healer and a dedicated pursuer of heretics, over whether God prefers to tend man's body or scourge his soul". ${ }^{1}$ The film tells the story of a thirteenth-century Dominican who, deployed to seek out heretics, arrives in a small French village where he discovers a mysterious lady who performs healing rites. Although it received mixed reviews, most notably from the American Historical Review ${ }^{2}$ the psychological exploration of trauma, secrecy, control and oppression, feminist ideas of patriarchy, childbirth and sexual violence, and moral themes of pride, lust, corruption, spiritual blindness, celibacy, virginity, and forgiveness, made it intriguing watching and scholars continue to regard it as an important ethno-historical film about the middle ages. ${ }^{3}$

The film Sorceress was based on an actual recorded event, like its more famous contemporary Le Retour de Martin Guerre (1982), for which the American historian of early modern France and professor at Princeton University, Natalie Zemon Davis, acted as a consultant and helped write the screenplay. Sorceress was a retelling of the medieval legend of

\footnotetext{
${ }^{1}$ Walter Goodman "Review / Film; "Sorceress": A Medieval Parable", The New York Times (1988), p.1.

${ }^{2}$ Katherine Anderson, Jill A. Frederick, Mary Suydam, Jacqueline E. Robbins, Joan Cadden, "Review: le moine et la sorcière [The Sorceress] by Paméla Berger; Annie Leibovici; Georges Reinhart; Suzanne Schiffman," The American Historical Review, Vol. 94, No. 4 (Oct., 1989), 1037-1039.

${ }^{3}$ Schmitt, "Post-Scriptum", p.63. There have also been numerous other offshoots e.g. a programme on French T.V. by Jean-Claude Schmitt, an installation by the Venezuelan artist José Antonio Hernằndez-Diez, as well as the founding of the "Association Saint Guignefort", see Schmitt, "Post-Scriptum", pp.62-4.
} 
St Guinefort, the Holy Greyhound, although it differed in some of its content from the original. ${ }^{4}$ In recent years the medieval tale has been much explored, most famously by the historian JeanClaude Schmitt, ${ }^{5}$ whose work on the holy greyhound has been translated into many languages. ${ }^{6}$ Nevertheless, as we shall explore, certain aspects of the tale require further examination.

Throughout its two thousand year history, Christianity has honoured animals as part of God's creation. ${ }^{7}$ In hagiographies they are the friends of saints with whom they are often depicted: ${ }^{8}$ John the Baptist and St Agnes with a lamb, St Bernard of Clairvaux with a little dog; St Dominic and St Roch also with a dog, St Antony of Egypt with a wolf; St Eustace with a stag. ${ }^{9}$ Saints also care for animals: another St Anthony was a swineherd and is often depicted with a pig, St Bridgid a dairymaid, St Bueno looked after livestock, St Cuthbert the eider ducks of the Farne Islands, St Jerome aided a lion, St Blaise cured sick animals, St Antony of Padua preached to the fishes and St Francis of Assisi to the birds, as well as taming the wolf of Gubbio. $^{10}$ The depiction of a saint with an animal was a way of emphasising the saint's attributes and thereby identifying him. ${ }^{11}$ Animals are also divine symbols: Jesus is the Lamb of God, the dove is the symbol of the Holy Spirit, the lion represents courage, the dog loyalty.

\footnotetext{
${ }^{4}$ For example, in the film, Stephen of Bourbon is depicted as having committed rape at an earlier stage in his career before becoming an inquisitor, something for which there is no historical evidence; see Jean-Claude Schmitt, "Post-Scriptum", in Saint-Guignefort: Légende, Archéologie, Histoire (Châtillon-sur-Chalaronne: Association Saint Guignefort, 2005), p.63.

${ }^{5}$ Jean-Louis Maret, "Préface", in Saint-Guignefort: Légende, Archéologie, Histoire (Châtillon-sur-Chalaronne: Association Saint Guignefort, 2005), p.3.

${ }^{6}$ Schmitt, "Post-Scriptum", p.62.

${ }^{7}$ Tessa Paul, The Complete Illustrated Encyclopedia of Saints (London: Hermes House, 2009), pp.146-7.

${ }^{8}$ David Salter, Holy and Noble Beasts: Encounters with Animals in Medieval Literature (Woodbridge: D.S. Brewer, 2001), p.7.

${ }^{9}$ Jacques Dubois, "Saint Guinefort Vénéré des Dombes. Comment un martyr inconnu fut substituté ằ un chien-martyr", Journal des savants (1980), 144.

${ }^{10}$ Yet we should note that if we look at the lives of St Francis, despite his relationship with the animal kingdom, his medieval biographers showed little interest in and attributed no intrinsic value to the creatures themselves, see Salter, Holy and Noble Beasts, p.7.

${ }^{11}$ Albert Leon Guérard, French Civilization from its Origins to the Close of the Middle Ages (Boston: Houston Mifflin, 1921), pp.155-6.
} 
Indeed the dog in particular became a Christian symbol for loyalty, conscientiousness, a guard against the devil and even a healer with curative properties. ${ }^{12}$ However, since biblical texts often also emphasised ideas such as religious impurity and the vices of gluttony, voraciousness and sexual appetite, some medieval writers used these negative canine associations in polemical writing to deliberately stigmatise both Jews and Muslims. ${ }^{13}$ In defence, we know that Jews in their own writings either turned the negative canine imagery back upon these Christian polemicists or deliberately embraced their supposed canine identity by emphasising its positive qualities. ${ }^{14}$ We should also note that in medieval writing heretics, the opposite of saints, are also depicted with certain animals: frogs, toads and especially cats.

It is therefore easy to see why in the middle ages animals were often associated with popular saints' cults. In the twelfth century as the business of canonising saints became enshrined in canon law and the papacy began to assume control of the process, a problem arose as to what to do about cults, including to animals, which were popular but had no historical or theological foundation. ${ }^{15}$ Thirteenth-century popes approved and licensed the Franciscan and Dominican Orders to teach and preach orthodox Christianity and to use their confessional skills to nourish, but also regularise, such popular religious expression. ${ }^{\mathbf{1 6}}$ The original brief of St Dominic, founder of the Dominicans, had been to preach and teach against the Cathars, ${ }^{17}$ and

\footnotetext{
12 Irven Resnick, “Good Dog / Bad Dog: Dogs in Medieval Religious Polemic", Ennarratio 18 (2013), 74-82, 84.

${ }^{13}$ Resnick, "Good Dog / Bad Dog”, 74-82, 84; Kenneth Stow, Jewish Dogs: An Image and Its Interpreters: Continuity in the Catholic-Jewish Encounter (Stanford, Calif., 2006), passim.

${ }^{14}$ Resnick, "Good Dog / Bad Dog”, 82-83, 84.

${ }^{15}$ Dubois, "Saint Guinefort Vénéré des Dombes", 146-7; Bernard Hamilton, Religion in the Medieval West (London: Edward Arnold, 1986), p.126.

${ }^{16}$ Clifford Hugh Lawrence, Medieval Monasticism: Forms of Religious Life in Western Europe in the Middle Ages, $4^{\text {th }}$ edn (Oxon: Routledge, 2015), pp.224-40; Peter Linehan, The Ladies of Zamora (Manchester: Manchester University Press, 1997), pp.7-10; Allen Dudley Severance, "Beatification and Canonization with Special Reference to Historic Proof and the Proof of Miracles", American Society of Church History. Papers of the American Society of Church History 2:3 (New York, 1912), 46.

${ }^{17}$ Lawrence, Medieval Monasticism, pp.233-4.
} 
we know he had considerable success amongst these heretics in southern France. ${ }^{18}$ For this reason a play was made on the name of the Dominicans: "Domini canes" - dogs of the Lord those who, like hounds, pursued souls in order to save them.

Pope Honorius III (1216-1227) confirmed the Dominican Order in his bulls 'Religiosam vitam' of December 1216, 'Gratiarum omnium largitori' of January $1217,{ }^{19}$ and 'Quoniam abundavit iniquitas' of $1220 .^{20}$ His successor Pope Gregory IX (1227-1241) increased papal privileges to both Orders, a highly significant move since any criticism of the friars now became a criticism of the papacy, ${ }^{21}$ and in 1231 he formally launched the inquisition in his papal bull 'Excommunicamus'. ${ }^{22}$ Through the bull 'Virtute conspicuos', Pope Alexander IV (1254-1261) further privileged the Dominicans, granting them independence from all Church authority except the pope. ${ }^{23}$ Though not all inquisitors were Dominicans, as for example Jacques Fournier, the future Pope Benedict XII (1334-1342), who became bishop of

${ }^{18}$ Emmanuel le Roy Ladurie, Montaillou: Cathars and Catholics in a French Village, 12941324, trans. Barbara Bray (Harmondsworth: Penguin, 1984), p.315.

${ }^{19}$ Honorius III, "Religiosam vitam eligentibus" (22 December 1216), Honorii III romani pontifices opera omnia quae extant, ed. Césare Auguste Horoy, 5 vols (Paris: Imprimerie de la Bibliothèque ecclésiastique, 1879-1882), Vol. 2, cols 141-4; see William Hinnesbuch, The History of the Dominican Order, Vol. 1, Origins and Growth to 1500 (Staten Island, N.Y.: Alba House, 1966), p.48; p.56. Honorius III also licensed the Franciscans to preach in 1220 and from then on papal bulls continued to endorse the two Orders. See, for example, Honorius III, "Gratiarum omnium largitori" (26 January 1217), Regesta pontificum Romanorum, ed. Auguste Potthast, 2 vols (Graz: Akademische Druck- u. Verlagsanstalt, 1957), Vol. 1, p.479, no.5434; Gregory IX, "Nimis iniqua" (21 August 1231), Regesta pontificum Romanorum, ed. Potthast, Vol. 1, p.754, no.8786a; Nicholas IV, "Excitamur ab intimis" (7 August 1289), Regesta pontificum Romanorum, ed. Potthast, Vol. 2, p.1857, no.23037; Nicholas IV, "Super montem catholicae" (17 August 1289), Regesta pontificum Romanorum, ed. Potthast, Vol. 2, p.1857, no.23044.

${ }^{20}$ Honorius III, “Quoniam abundavit iniquitas” (6 May 1220), Opera Omnia, ed. Horoy, Vol. 3, cols 424-5; John Freed, The Friars and German Society in the Thirteenth Century (Cambridge, Mass: Medieval Academy of America, 1977), p.12.

${ }^{21}$ For example, Gregory IX, "Nimis iniqua" (21 August 1231), in, Regesta pontificum Romanorum, ed. Potthast, Vol. 1, p.754, no.8786a.

${ }^{22}$ Gregory IX, "Excommunicamus et anathematizamus" (February 1231), Les Registres de Gregoire IX, ed. Lucien Auvray, 4 vols, Bibliothèques des écoles françaises d'Athènes et de Rome ( $2^{\text {nd }}$ Series), (Paris: Boccard, 1890-1955), Vol. 1, pp.351-2.

${ }^{23}$ Linehan, The Ladies of Zamora, p.13. 
Pamiers in 1317 and organised enquiries against heretics in the south of France ${ }^{24}$ nevertheless, the Dominicans soon became the leading force behind the Inquisition.

One such Dominican inquisitor was Stephen of Bourbon (d. circa 1261). Not much is known about his origins, but according to his near contemporary, the fellow Dominican inquisitor Bernard Gui (1261/2-1331), he was born from a noble family in Belleville. ${ }^{25}$ We also know that he was born between 1190 and 1195, that he studied in Paris around 1215, that he joined the Dominican priory at Lyon around $1223,{ }^{26}$ and that he was appointed as an inquisitor in $1236 .{ }^{27} \mathrm{He}$ was both a determined preacher and a confessor, and it was through his hearing of confessions that he got to know many local customs. ${ }^{28}$ He was active in France in the districts of Lyonnais, Burgundy, Franche- Comté, Savoy, Champagne, Lorraine, Auvergne, Languedoc, and Roussillon from the 1230s. From descriptions of his activities in these areas historians have been able to plot his exact whereabouts, including his discovery of the cult of St Guinefort. ${ }^{29}$

\footnotetext{
${ }^{24}$ le Roy Ladurie, Montaillou, p.xi; Daniel Fabre and Jacques Lacroix, "Pour une anthropologie des collectivités rurales occitanes", in Communautés du Sud. Contribution à l'anthropologie des collectivités rurales occitanes, ed. Daniel Fabre and Jacques Lacroix (Paris, 1975), Vol. 1, p.21; Emmanuel le Roy Ladurie, "La Domus a Montaillou et en Haute Ariège au XIVe Siècle", Communautés du Sud. Contribution ằ l'anthropologie des collectivités rurales occitanes, ed. Daniel Fabre and Jacques Lacroix (Paris, 1975), Vol. 1, pp.166-220, passim.

${ }^{25}$ Jacques Berlioz, "De l'homme aux pois au Saint Lévrier: le dominicain Etienne de Bourbon (mort vers 1261) dans la Dombes", in Saint-Guignefort: Légende, Archéologie, Histoire (Châtillon-sur-Chalaronne: Association Saint Guignefort, 2005), pp.28-9; p.41. ${ }^{26}$ Jacques Berlioz, "Introduction" to Stephen of Bourbon, "Tractatus de Diversis Materiis Praedicabilibus", ed. Jacques Berlioz (and Jean-Luc Eichenlaub), (Turnhout, 2002), pp.XXIXXIV; Berlioz, "De l'homme aux pois au Saint Lévrier", pp.29-31.

${ }^{27}$ Berlioz, "Introduction" to Stephen of Bourbon, "Tractatus de Diversis Materiis Praedicabilibus", ed. Berlioz (and Eichenlaub), p.XXVII.

${ }^{28}$ Berlioz, "De l'homme aux pois au Saint Lévrier", p.32.

${ }^{29}$ Jacques Berlioz, "Appendix", in "De l'homme aux pois au Saint Lévrier: le dominicain Etienne de Bourbon (mort vers 1261) dans la Dombes", in Saint-Guignefort: Légende, Archéologie, Histoire (Châtillon-sur-Chalaronne: Association Saint Guignefort, 2005), pp.435.
} 
Stephen composed a work known either as the De septem donis Spiritus Sancti (On the Seven Gifts of the Holy Spirit), ${ }^{30}$ or the Tractatus de diversis materiis praedicabilibus, which drew on his experience as a preacher and inquisitor. ${ }^{31}$ The title of his treatise reflected contemporary Cistercian spirituality whose pedagogy was aimed at directing the conscience, as to be found in the works of Bernard of Clairvaux and Adam de Perseigne and also in the Life of Saint Marie d'Oignies composed by James of Vitry. ${ }^{32}$ It was preserved in a number of manuscripts, including an important one from Paris - Ms. Paris, BnF, lat. $15970 .{ }^{33}$ It appears to have been intended for a similar purpose to the better-known Dialogus miraculorum of another famous contemporary, the Cistercian Caesarius of Heisterbach (1219-1223). ${ }^{34}$

Stephen's missionary activity took place between 1223 and circa 1250, after which he retired to the Dominican priory at Lyons where he composed his treatise of exampla. ${ }^{35} \mathrm{We}$ know from this work that just before 1261 he visited an area of south-eastern France known as

${ }^{30}$ Berlioz, "Introduction" to Stephen of Bourbon, "Tractatus de Diversis Materiis Praedicabilibus", ed. Berlioz (and Eichenlaub), pp.XXXVIII-IX

${ }^{31}$ Stephen of Bourbon, "De Supersticione" in "De septem donis Spiritus Sancti", or "Tractatus de diversis Materiis Praedicabilibus", in Anecdotes Historiques, Legends et Apologues Tires de Receuil inedit d'Etienne de Bourbon, ed. Albert Lecoy de March, (Paris: La Société de l'Histoire de France, 1877), pp.314-29; the story of St Guinefort is on pp.3258. For an English translation see "De Supersticione", Medieval Sourcebook, Fordham University (online), trans. Paul Halsall; for a French translation see Etienne of Bourbon, Exemplum, trans. Jean-Claude Schmitt in Saint-Guignefort: Légende, Archéologie, Histoire (Châtillon-sur-Chalaronn: Association Saint Guignefort, 2005), pp.4-5. See Dubois, "Saint Guinefort Vénéré des Dombes", 147.

${ }^{32}$ Berlioz, "De l'homme aux pois au Saint Lévrier", pp.35-6.

${ }^{33}$ Berlioz, "Introduction' to Stephen of Bourbon, 'Tractatus de Diversis Materiis Praedicabilibus", ed. Berlioz (and Eichenlaub), p.XLV, p.XLVII.

${ }^{34}$ Caesarius of Heisterbach, The Dialogue on Miracles: Caesarius of Heisterbach (12201235), trans. Henry von E. Scott and Charles Cook Swinton Bland, with intro. by George Gordon Coulton (London: G. Routledge and Sons, 1929); Schmitt, The Holy Greyhound, p.2; Doulet, Quand les démons enlevaient les enfants, p.110; Berlioz, "Introduction" in Stephen of Bourbon, "Tractatus de Diversis Materiis Praedicabilibus”, ed. Berlioz (and Eichenlaub), p.XIX; p.XXXIII.

${ }^{35}$ Berlioz, "Introduction" to Stephen of Bourbon, "Tractatus de Diversis Materiis Praedicabilibus”, ed. Berlioz (and Eichenlaub), p.XXX. 
the Dombes, in the diocese of Lyons, ${ }^{36}$ and there found that women were venerating a certain St Guinefort as a healer of children. ${ }^{37}$ He was extremely pleased to hear this, until he discovered that St Guinefort was not a holy man, but a greyhound. ${ }^{38} \mathrm{He}$ recorded the incident in "De Supersticione", one section of the De septem donis Spiritus Sancti, which described a range of superstitious cults:

This recently happened in the diocese of Lyons where, when I preached against the reading of oracles, and was hearing confession, numerous women confessed that they had taken their children to Saint Guinefort. As I thought that this was some holy person, I continued with my enquiry and finally learned that this was actually a greyhound, which had been killed in the following manner.

In the diocese of Lyons, near the enclosed nuns' village called Neuville, on the estate of the Lord of Villars, was a castle, the lord of which and his wife had a baby boy. One day, when the lord and lady had gone out of the house, and the nurse had done likewise, leaving the baby alone in the cradle, a huge serpent entered the house and approached the baby's cradle. Seeing this, the greyhound, which had remained behind, chased the serpent and, attacking it beneath the cradle, upset the cradle and bit the serpent all over, which defended itself, biting the dog equally severely. Finally, the dog killed it and threw it well away from the cradle. The cradle, the floor, the dog's mouth and head were all drenched in the serpent's blood. Although badly hurt by the serpent, the dog remained on guard beside the cradle. When the nurse came back and saw all this she thought that the dog had devoured the child, and let out a scream of misery. Hearing it the child's mother also ran up, looked, thought the same thing and screamed too. Likewise the knight, when he arrived, thought the same thing and drew his sword and killed the dog. Then, when they went closer to the baby they found it safe and sound, sleeping peacefully. Casting around for some explanation, they discovered the serpent, torn to pieces by the dog's bites, and now dead. Realising then the true facts of the matter, and deeply regretting having unjustly killed so useful a dog they threw it into a well in front of the manor door, threw a great pile of stones on top of it, and planted trees beside it, in memory of the event. ${ }^{39}$

We know that such a story of a hound which saves a baby's life but is then killed by its master, ${ }^{40}$ is found in many places and periods: we should note that the motif appears, for

\footnotetext{
${ }^{36}$ Berlioz, "Introduction" to Stephen of Bourbon, "Tractatus de Diversis Materiis Praedicabilibus", ed. Berlioz (and Eichenlaub), p.XXV.

${ }^{37}$ Berlioz, "Introduction" to Stephen of Bourbon, "Tractatus de Diversis Materiis Praedicabilibus", ed. Berlioz (and Eichenlaub), p.XXVI.

${ }^{38}$ Hamilton, Religion in the Medieval West, p. 126.

${ }^{39}$ Stephen of Bourbon, "De Supersticione", pp.325-6.

${ }^{40}$ Jean-Pierre Poly, Guinefort et les faramans des Dombes. Un example d'anthropologie médiévale (Paris 69: Raison présente, 1984), p.123.
} 
example, in the modern Disney classic Lady and the Tramp (1955). ${ }^{41}$ Scholars have pointed to a sixth century B.C. Sanskrit version from India, a Greek version recorded by Pausanias circa A.D. 160-80, and an Arabic version translated into Greek, then Hebrew, then Latin. ${ }^{42}$ Yet this first Latin translation does not appear in the West until several years after Stephen of Bourbon's death, which suggests that the story he heard was not related to any of these. ${ }^{43}$ Furthermore, the peasants who made their confessions to Stephen were not just repeating a tale; they regarded the greyhound's death as a matter of fact, not fiction; indeed this made him the inquisitor believe in its authenticity and the more determined to suppress it. ${ }^{44}$

Nevertheless, the tale is certainly the product of folk culture. ${ }^{45}$ It may represent a Christian form of an originally pagan cult, similar to the dog-headed St Christopher venerated in the Eastern Orthodox Church. ${ }^{46}$ The Ancient Egyptian God Anubis had a dog's head and the idea of St Christopher as "dog-headed" seems to have arisen out of a confusion between the Latin words "Cananeus" ("Cananinte") and "canineus" ("canine"). That the dog is a hound is also important. In medieval literature animals tend to reflect their feudal owners; hence the depiction of "noble" beasts such as falcons, horses, lions and also hounds. ${ }^{47}$ Hence we have the "faithful hound" motif, ${ }^{48}$ such as we find in the Welsh story of the faithful Gelert which derives

\footnotetext{
${ }^{41}$ Lady and the Tramp (Disney Movies, 1955).

${ }^{42}$ Jean-Claude Schmitt, The Holy Greyhound: Guinefort, Healer of Children since the Thirteenth Century, trans. Martin Thom (Cambridge: Cambridge University Press, 1983), pp.40-1.

${ }^{43}$ Schmitt, The Holy Greyhound, p.41; George Lyman Kittredge, "Arthur and Golagan”, Studies and Notes in Philology and Literature, Vol. VIII (Cambridge, Mass.: Harvard University Press, 1903), p.272.

${ }^{44}$ Schmitt, The Holy Greyhound, p.39.

${ }^{45}$ Schmitt, The Holy Greyhound, p.67. For discussion of the controversial idea that exposing infants to snakes was regarded as a paternity test see the work by Richard Firth Green, Elf Queens and Holy Friars: Fairy Beliefs and the Medieval Church (Philadelphia, Pennsylvania: University of Pennsylvania Press, 2016), p.116.

${ }^{46}$ Dubois, "Saint Guinefort Vénéré des Dombes", 154; Hamilton, Religion in the Medieval West, p.126.

${ }^{47}$ Salter, Holy and Noble Beasts, p.8.

${ }^{48}$ Kittredge, “Arthur and Golagan”, pp.222-3; pp.269-74.
} 
from the thirteenth century; ${ }^{49}$ this early saint - also known as Kilart or Calert - was from the village of Beddgelert in Wales. The greyhound is a hunting dog, a faithful companion to the lord of the manor, who represents the local aristocracy; ${ }^{50}$ that makes the master's crime of killing it even more shocking.

The legend of St Guinefort later entered the popular medieval collection The Seven Sages of Rome, a collection of moral stories or exempla form the fourteenth century. ${ }^{51}$ In this version there is an emphasis on the goodness and nobility of the hound who saves the baby's life:

Out of the walle scho [the snake] came;

Into the halle the way scho name,

And drow hym toward the credile perbyne

To sle the child that was therinne.

Toward the credyl as he suythe

The good grewhond lay and syze,

And was swythe wrothe withalle

That he cam into the [h]alle.

The grewhond stood vppe anon,

And to the naddir [adder] he gan goon.

Ther thay faugthen togydir long,

And ayther wondid othyr strong.

As thay foghten, here ze moun,

The credyl went vppesodoun.

The credyl vppon the pomels stoode;

The child hadde nought bote goode.

Hyt no woke, no hyt no wyppe,

Bote [lay] alle stille and sleppe.

The grewhond zede the worme so nyghe

That into the zerd the worme flyghe.

The grewhonde sewed hym so faste

${ }^{49}$ Schmitt, The Holy Greyhound, p.46; A Medieval Garner. Human Documents from the Four Centuries Preceding the Reformation, ed. and trans. George Gordon Coulton (London:

Constable and Company Ltd., 1910), p.308; William Copeland Borlase, The Age of the

Saints: a Monograph of Early Christianity in Cornwall with the Legends of the Cornish

Saints, And an Introduction Illustrative of the Ethnology of the District, $2^{\text {nd }}$ ed. (Truro: J.

Pollard, 1895), pp.90-1.

${ }^{50}$ Berlioz, "De 1'homme aux pois au Saint Lévrier", p.41.

${ }^{51}$ The Seven Sages of Rome (Midland Version), ed. Jill Whitelock (Oxford: Oxford University Press, 2005); for a French translation see 'Les septs sages de Rome', ed. JeanMichel Poisson, in Saint-Guignefort: Légende, Archéologie, Histoire (Châtillon-surChalaronne: Association Saint Guignefort, 2005), p.24; see also Green, Elf Queens and Holy Friars, p.116. 
That he slew hym at the last.

Tho the naddir [adder] was falle

The greuhonde layde hym in the halle,

Euelle wondyd oueralle,

And forsothe he lay and zal. ${ }^{52}$

Yet the greyhound in the Sevan Sages of Rome is not named. Why does the loyal greyhound in Stephen of Bourbon's account bear the name 'Saint Guinefort'? ${ }^{53}$ We know from two manuscripts, the "Passio Sancti Guiniforti" and the "Miracula Sancti Guniforti", the first a narrative preserved at the Lateran in Rome, the second a narrative plus a list of miracles preserved at Novare, that a "Life of Saint Guinefort" was written sometime between the eighth and twelfth centuries. ${ }^{54}$ According to legend, Saint Guinefort lived during the reigns of the Emperors Diocletian (284-305 A.D.) and Maximian (286-305 A.D.), was executed for his preaching of Christianity and died a martyr saint at Pavia, in the diocese of Milan, where his cult was established. ${ }^{55}$ The veneration of this Saint Guinefort of Pavia then spread throughout France and spawned numerous cult sites. ${ }^{56}$ It seems that Cluniac monks probably spread his cult to the west of the Alps from the end of the eleventh century and that he was venerated at Cluny abbey from the twelfth century onwards. ${ }^{57}$

Possibly this veneration of St Guinefort is the source for the name of the cult discovered by Stephen of Bourbon. Yet the region also boasted other cults such as that of Saint Genefort, ${ }^{58}$ Saint Guinefort of Bourges, ${ }^{59}$ and Saint Guinefort of Sens. ${ }^{60}$ Furthermore, we know of a

\footnotetext{
${ }^{52}$ The Seven Sages of Rome (Midland Version), ed. Whitelock, lines 776-801.

${ }^{53}$ Resnick, "Good Dog / Bad Dog”, 80.

${ }^{54}$ Dubois, "Saint Guinefort Vénéré des Dombes", 145-6; Schmitt, The Holy Greyhound, p.91.

${ }^{55}$ Schmitt, The Holy Greyhound, p.92; Hamilton, Religion in the Medieval West, p.126;

Carole Larché Milon, "Du chien Guignefort aux saints Guinefort", in Saint-Guignefort:

Légende, Archéologie, Histoire (Châtillon-sur-Chalaronne: Association Saint Guignefort, 2005), p.48.

${ }^{56}$ Schmitt, The Holy Greyhound, p.106.

${ }^{57}$ Dubois, "Saint Guinefort Vénéré des Dombes", 150-3; Larché Milon, "Du chien Guignefort aux saints Guinefort", p.50.

${ }^{58}$ Larché Milon, "Du chien Guignefort aux saints Guinefort", p.47; p.49.

${ }^{59}$ Larché Milon, "Du chien Guignefort aux saints Guinefort", p.51.

${ }^{60}$ Larché Milon, "Du chien Guignefort aux saints Guinefort”, p.51.
} 
number of other saints who were also regarded as healers of children and may have been associated with Saint Guinefort, including Saint Millefort, who was supposed to have lived in Scotland at the beginning of the twelfth century and about whom there are two distinct legends, ${ }^{61}$ Saint Dignefort, bishop of Meaux and martyr who attained cult status in Normandy from the second half of the fifteenth century onwards, ${ }^{62}$ and Sainte Wilgeforte, the daughter of a Portuguese king and supposedly martyred in 139 A.D., whose story became well known in France in the fourteenth century, ${ }^{63}$ and who was particularly associated with the curing of problems associated with marriage. ${ }^{64}$

All these saints, with the exception of our Saint Guinefort, were in human, not animal form. ${ }^{65}$ Yet, what united all these saints and their cults which spread all over France was the idea that they possessed the faculty to cure children of different illnesses and afflictions. ${ }^{6667}$ Furthermore, formulations of invocations to these saints reveal that all were associated not just with the curing of children, but with the power to determine whether a child would live or die, an idea to which we will return. ${ }^{68}$ Indeed some of their cult sites were shut down by the Church in the eighteenth century, not least because pilgrims seem to have been using them, not to invoke healing of their child, but to invoke the death of perceived wrongdoers, another theme to which we shall return. ${ }^{69}$

Yet since our only source for Saint Guinefort the holy greyhound is Stephen of Bourbon's "De Supersticione" we do not know much about the cult in the Dombes, nor how

\footnotetext{
${ }^{61}$ Larché Milon, "Du chien Guignefort aux saints Guinefort", pp.52-4.

${ }^{62}$ Larché Milon, "Du chien Guignefort aux saints Guinefort", p.54.

${ }^{63}$ Larché Milon, "Du chien Guignefort aux saints Guinefort”, pp.54-5.

${ }^{64}$ Larché Milon, "Du chien Guignefort aux saints Guinefort", p.60.

${ }^{65}$ Larché Milon, "Du Chien Guignefort aux Saints Guinefort", p.48; p.60.

${ }^{66}$ Larché Milon, "Du chien Guignefort aux saints Guinefort", p.55.

${ }^{67}$ Larché Milon, "Du chien Guignefort aux saints Guinefort", pp.56-7; p.58.

${ }^{68}$ Larché Milon, "Du chien Guignefort aux saints Guinefort", p.59.

${ }^{69}$ Larché Milon, “Du chien Guignefort aux saints Guinefort”, pp.59-60.
} 
old it was. What we do know is that it became a known place of pilgrimage. ${ }^{70}$ According to the "De Supersticione", Stephen's reaction on hearing of the cult was to visit its location in a nearby wood and to disinter and burn the greyhound's remains: ${ }^{71}$

We went to this place, we called together all the people on the estate, and we preached against everything that had been said. We had the dead dog disinterred, and the sacred wood cut down and burnt, along with the remains of the dog. And I had an edict passed by the lords of the estate, warning that anyone going thenceforth to that place for any such reason would be liable to have his possessions seized and then sold. ${ }^{72}$

We should note that the word "people" is used as a term in ecclesiastical discourse to refer to the Christian community of the diocese or parish. ${ }^{73}$ Furthermore, archaeological exploration has located the "wood" as two kilometres to the south-east of Châtillon-sur-Chalaronne and as bearing all the signs of a place of a site of medieval pilgrimage. ${ }^{74}$ Indeed, although Stephen had the site destroyed, we know that it remained a site of pilgrimage for mothers with sick children for many centuries to come. ${ }^{75}$

Stephen of Bourbon's action is not surprising. He was not worried so much that the people of the Dombes were worshipping the greyhound as a substitute for God, but that it was taking on the role of a saint because acting as an intermediary between themselves and God. ${ }^{76}$ As we have noted, the medieval Church increasingly attempted to regulate saints' cults and certainly did not approve of the veneration of animals. The only non-human creatures the Church allowed prayer to were angels: one could pray to St Michael, commander of the host

\footnotetext{
${ }^{70}$ Schmitt, The Holy Greyhound, pp.68-70.

${ }^{71}$ Hamilton, Religion in the Medieval West, p.126; Larché Milon, "Du chien Guignefort aux saints Guinefort", p.48. .

${ }^{72}$ Stephen of Bourbon, "De Supersticione", pp.327-8.

${ }^{73}$ Berlioz, "De l'homme aux pois au Saint Lévrier", p.41.

${ }^{74}$ Jean Michel Poisson, "Recherches archeologiques dans le bois de Saint-Guignefort", in Saint-Guignefort: Légende, Archéologie, Histoire (Châtillon-sur-Chalaronne: Association Saint Guignefort, 2005), pp.7-23.

${ }^{75}$ Berlioz, "De l'homme aux pois au Saint Lévrier", p.41.

${ }^{76}$ Dubois, "Saint Guinefort Vénéré des Dombes", 154.
} 
of heaven, and we know that soldiers, in particular Normans, venerated him at Mont SaintMichel in Brittany and Monte Gargano in Apulia. ${ }^{77}$

The reason for the Church's disapproval was philosophical, concerned with the difference between choice / assent and instinct. Animals could not be saints because they lacked will and so could not choose right or wrong, nor make or reject moral claims. Here the medieval clergy were reliant on a very few references to animals and their place in creation in the works of the Church Fathers. St Augustine (354-430) in the City of God made a distinction between irrational animals who 'desire nothing beyond the proper arrangement of the body's parts and the satisfaction of our appetites', and man who possessed a rational soul and who 'subordinates all that he has in common with the beasts to the peace of that rational soul. He does this so that his mind may engage to some degree in contemplation,...thereby displaying that ordered agreement of thought and action which, as we have said, constitutes the peace of the rational soul. ${ }^{78}$

Even further back in time, Aristotle (384-322 BC) in the De Anima had described animals as having no capacity beyond perception. He had argued that all living things grow, nourish and produce themselves; that animals do all these things and also move and perceive, but only humans do all of these and also reason. ${ }^{79}$

And of those creatures that perceive, some have the locomotive faculty, others do not. Ultimately and most rarely, some have reasoning and thinking. ${ }^{80}$

These ideas do therefore come from Aristotle (and from others) but from works which Augustine had not read. They were in fact commonplace among both pagans and Christians.

\footnotetext{
${ }^{77}$ Hamilton, Religion in the Medieval West, p.126.

${ }^{78}$ St Augustine, The City of God against the Pagans, ed. and trans. Robert W. Dyson (Cambridge, New York: Cambridge University Press, 1998), Book 19, Chapter 14, pp.940-1. ${ }^{79}$ Aristotle, De Anima, trans. Hugh Lawson-Tancred (London: Penguin Books, 1986), pp.155-64.

${ }^{80}$ Aristotle, De Anima, trans. Lawson-Tancred, p.163.
} 
Thomas Aquinas (1225-1274) had of course read the relevant Aristotelian texts in Latin translation. Aquinas, an exact contemporary of Stephen of Bourbon, and who wrote a commentary on Aristotle's De Anima, argued that whereas human beings engaged in rational thought, animals acted purely on instinct. ${ }^{81}$ For Aquinas the Rational Soul, as distinct from the Vegetative Soul or Sensitive Soul, is found only in human beings and accounts for the ability they have to reason and engage in higher order cognitive function, in particular knowledge of universals. Human reason accounts for our non-sensory knowledge, our knowledge of universals, and our ability to be self-aware:

There exists, therefore, an operation of the soul which so far exceeds the corporeal nature that it is not even performed by any corporeal organ; and such is the operation of the rational soul." 82

Furthermore, he states that the Rational Soul:

"regards a still more universal object - namely, not only the sensible body, but all being in universal." 83

Hence Thomas Aquinas recognized a kind of concrete reasoning in animals, the 'vis aestimativa' - what marks humans off is that the reasoning involves self-conscious thinking about abstractions. ${ }^{84}$

Although it is unlikely that Stephen of Bourbon would have known of the teachings of his contemporary, Thomas Aquinas, his dismay to discover the good people of the Dombes worshipping a greyhound was based on a tradition stemming back to the Ancient World that

${ }^{81}$ Aristotle's De Anima in the Version of William of Moerbeke and the Commentary of St Thomas Aquinas, trans. Kenelm Foster and Silvester Humphries with an Intro. by Ivo Thomas (London: Routledge and Keegan Paul, 1951), pp.163-78; see also Thomas Aquinas, On Human Nature, ed. with Intro. by Thomas S. Hibbs (Indianapolis, Cambridge: Hackett, 1999), pp.107-19; Dubois, "Saint Guinefort Vénéré des Dombes", 143.

${ }^{82}$ The "Summa Theologica" of St. Thomas Aquinas, Part 1. QQ. 75-119, trans. Fathers of the English Dominican Province (London: Burns Oates and Washbourne Ltd, 1912), Q78, Art.1, Obj. 4, p.76.

${ }^{83}$ The "Summa Theologica”, p.77, Q78, Art.1, Obj. 4, p.76.

${ }^{84}$ David d'Avray, Rationalities in History: A Weberian Essay in Comparison (Cambridge: Cambridge University Press, 2010), passim. 
since animals were not rational beings with the capacity to make moral choices they did not actively choose good over evil and so could not be saints. Yet this was not the only reason for Stephen's dismay. According to the "De Supersticione" there was something much more sinister going on in what appeared to be an innocent, if unorthodox, veneration of a greyhound:

...But the peasants, hearing of the dog's conduct and of how it had been killed, although innocent, and for a deed for which it might have expected praise, visited the place, honoured the dog as a martyr, prayed to it when they were sick or in need of something, and many there fell victim to the enticements and illusions of the devil, who in this way used to lead men into error. Above all, though, it was women with sick or weak children who took them to this place. They would go and seek out an old woman in a fortified town a league distant and she taught them the rituals they should enact in order to make offerings to demons, and in order to invoke them and she led them to the place. When they arrived, they would make offerings of salt and other things; they would hang their babies' swaddling-clothes on the bushes roundabout: they would drive nails into the trees which had grown in this place; they would pass the naked babies between the trunks of two trees the mother, on one side, held the baby and threw it nine times to the old woman, who was on the other side. Invoking the demons, they called upon the fauns in the forest of Rimite to take the sick, feeble child which, they said, was theirs, and to return their child that the fauns had taken away, fat and well, safe and sound.

Having done this, the infanticidal mothers took their children and laid them naked at the foot of the tree on straw from the cradle; then, using the light they had brought with them, they lit two candles, each an inch long, one on each side of the child's head and fixed them in - the trunk above it. Then they withdrew until the candles had burnt out, so as not to see the child or hear him crying. Several people have told us that while the candles were burning like this they burnt and killed several babies. $^{85}$

What are to make of the story? It is possible that the idea of exposing infants to snakes was regarded as a form of paternity test,${ }^{86}$ and that this piece of folklore is present in the story of Guinefort the Holy Greyhound. The historian Richard Firth Green argues that the idea of the changeling was associated with issues of legitimacy and that "it is surely no co-incidence that a serpent-killing dog should become the patron saint of fairy abductees". ${ }^{87}$ More obviously significant is the power of the "old woman" who stage manages the ritual. Throughout the rite,

\footnotetext{
${ }^{85}$ Stephen of Bourbon, "De Supersticione", pp.326-7.

${ }^{86}$ Green, Elf Queens and Holy Friars, p.116.

${ }^{87}$ Green, Elf Queens and Holy Friars, p.116.
} 
the old woman, who teaches the rituals and supervises them is central to the cult. ${ }^{88}$ Indeed Schmitt has pointed out that such rituals were still being overseen by women such as "Fancchette Gadin" who was said to cure babies as late as the early twentieth century. ${ }^{89}$ What is also very clear is that the cult described is a peculiarly female rite where the mother has the final say as to whether or not to accept the child as hers. ${ }^{90}$ This reflects the fact that in the medieval period, as in many historical eras, the paternity of a child could not always easily be proved, but the identity of the mother could be established with certainty. ${ }^{91}$

The rite described is made up of three parts. ${ }^{92}$ The first part is the giving of offerings. ${ }^{93}$ The second part is the building of a connection between the sick child and the greyhound's carcass through the use of certain intermediaries: clothes, nails, wood and the roots of trees. ${ }^{94}$ We seem to be dealing with a rite of protection..$^{95}$ The wood in medieval literature is symbolically a place of uncertainty and ambiguity where borders and boundaries are often blurred. ${ }^{96}$ The passing of a sick child through the opening between the trunks of two trees seems to have been and to remain a common folk practice. ${ }^{97}$ Thus the idea of parents passing sick children through the hole of a tree believed to possess magical and healing powers was found in Sweden as late as the 1930s and is also common in Celtic lore, as is idea of passing sick children through stone holes, or clefts of rock. ${ }^{98}$ Furthermore, the draping of children's

\footnotetext{
${ }^{88}$ Dubois, "Saint Guinefort Vénéré des Dombes", 150; Doulet, Quand les démons enlevaient les enfants, pp.108-9.

${ }^{89}$ Schmitt, "Post-Scriptum", p.61; Schmitt, The Holy Greyhound, passim.

${ }^{90}$ Jean-Michel Doulet, Quand les démons enlevaient les enfants. Les changelins: étude d'une figure mythique (Paris, 2002), pp.92-3.

${ }^{91}$ Doulet, Quand les démons enlevaient les enfants, pp.92-3.

${ }^{92}$ According to Doulet the rite was made up of two sequences (1) the invoking of the fauns and (2) the return and verification of the child; according to Schmitt it is tri-partite, see Doulet, Quand les démons enlevaient les enfants, p.89; p.90.

${ }^{93}$ Schmitt, The Holy Greyhound, p.71; Borlase, The Age of the Saints, p.104.

${ }^{94}$ Schmitt, The Holy Greyhound, pp.70-1.

${ }^{95}$ Doulet, Quand les démons enlevaient les enfants, pp.65-8.

${ }^{96}$ Fabre and Lacroix, "Pour une anthropologie des collectivités rurales occitanes", p.18.

${ }^{97}$ Schmitt, The Holy Greyhound, p.72; Borlase, The Age of the Saints, p.90.

${ }^{98}$ Borlase, The Age of the Saints, pp.89-91.
} 
clothing over bushes and the driving of nails into barks of trees were believed to transfer sickness from the body to the natural world. ${ }^{99}$

The second part of the ceremony should be viewed as rite of substitution. ${ }^{100}$ In this second part the mother and child are separated and the "fauns" - or demons - supposedly intervene. We witness here a community which believed in the power of changelings, "spirits" (dwarfs or fairies) ${ }^{101}$ who spirited away children and substituted their own. ${ }^{102}$ Since the mother believed there had been a first substitution - that the "fauns" had substituted her child for a changeling, so now there must be a second, reverse substitution to restore the status quo in which the mother recovers her child and the "fauns" their changeling. ${ }^{103}$ Finally, the third part of the ritual proves the efficacy of what has taken place: if the infant dies, the "fauns" have not agreed to restore it, but if it survives this is proof that they have restored the healthy child to its mother. ${ }^{104}$ Thus, the two agents of the substitution are the demons - represented here by the "fauns" or fairies - and the sorcerers - those who conjure up their existence - as represented here by the old woman. ${ }^{105}$

What are we to make of this description of the rite by Stephen of Bourbon? Our first instinct may be to discount the nature of the evidence and to dismiss the story as untrue. Perhaps, since it is written by a man, it should not be trusted to give accurate information about a female rite. However, although we know that some medieval clergy were misogynistic, we have no reason to think Stephen had in this instance any particular anti-female agenda. We

\footnotetext{
${ }^{99}$ Schmitt, The Holy Greyhound, pp.72-3; Borlase, The Age of the Saints, p.91; p.103.

${ }^{100}$ Doulet, Quand les démons enlevaient les enfants, pp.69-71.

101 Jean-Michel Doulet, Quand les démons enlevaient les enfants, pp.17-34.

${ }^{102}$ Schmitt, The Holy Greyhound, p.74; Doulet, Quand les démons enlevaient les enfants, p.84.

${ }^{103}$ Schmitt, The Holy Greyhound, p.71.

${ }^{104}$ Schmitt, The Holy Greyhound, p.72

${ }^{105}$ Doulet, Quand les démons enlevaient les enfants, p.117.
} 
might be more reasonably wary of the story's veracity because it was written by a Dominican inquisitor with his own agenda: to assert orthodox Christian theology through papal authority.

Yet Stephen's treatise De septem donis Spiritus Sancti was not only a theological commentary on the gifts of the Holy Spirit. It was also one of the earliest compilations of edifying anecdotes, or exempla, based on real life instances, which preachers collected as helpful aids for composing their sermons. ${ }^{106}$ The aim of the treatise appears to be tri-fold: to inspire in its readers or listeners a fear of eternal damnation, to point to the way of salvation and to defend against the vices. Hence the exempla were supposed to be aides-memoires which faithful Christians could draw on after a sermon. ${ }^{107}$ Some exempla appear to have derived from Stephen's own experience as a preacher, some from witnesses - either clergy or laity - whom he cited and some from other authorities such as the lives of saints, historical works and encyclopaedias, all of which he would have had easy access to in prior library at Lyons. ${ }^{108}$

Stephen tells us that he is concerned with "heretical depravity" and "the vain cult of divinations, incantations, oracles, the diverse devilish delusions by which the Devil attacks the Christian people". ${ }^{109}$ In particular he emphasises he is concerned with:

...offensive superstitions, some of which are offensive to God, others to our fellow men. Offensive to God are those who honour demons or other creatures as if they were divine: it is what idolatry does, and it is what the wretched women who cast lots do, who seek salvation by worshipping elder trees or making offerings to them; scorning churches and holy relics, they take their children to these elder trees, or to anthills, or to other things in order that a cure may be effected. ${ }^{110}$

Hence the activities of the peasants of the Dombes are suspect on a number of counts.

First, they are idolatrous, since divine honour is being shown to an animal, a dog. Second, the

${ }^{106}$ Schmitt, The Holy Greyhound, p.2; Doulet, Quand les démons enlevaient les enfants, p.88; p.99; Berlioz, "Introduction" to Stephen of Bourbon, "Tractatus de Diversis Materiis

Praedicabilibus”, ed. Berlioz (and Eichenlaub), p.XXXI.

${ }^{107}$ Berlioz, "De l'homme aux pois au Saint Lévrier", p.37.

108 Berlioz, "De l'homme aux pois au Saint Lévrier", p.36.

${ }^{109}$ Stephen of Bourbon, "De Supersticione", p.314.

${ }^{110}$ Stephen of Bourbon, "De Supersticione", p.325. 
women are involving themselves in other practices condemned by the Church: divination - the casting of lots to know God's plans in advance. Divination is the practise of seeking knowledge of the future or the unknown by supernatural means and Cleromancy in particular is a form of sortation - the casting of lots, which it was Stephen's duty as an inquisitor to prevent. ${ }^{111}$ Third, they are engaging with natural elements associated with witchcraft, in this case elder trees (flowers) and anthills, ${ }^{112}$ instead of with the Church's sanctioned vehicles of Grace, namely relics and the Sacraments. Fourth, they are a mockery of true pilgrimage and veneration of the canonical saints. ${ }^{113}$

So far this all seems relatively standard condemnation of unorthodox and un-sanctioned worship which it would have been standard for the papal inquisition to condemn as heretical and a deviance from the Faith, against which an inquisitor would have seen it as his duty to intervene. ${ }^{114}$ Yet, according to Stephen's account there was more than heresy going on. We are presented with a description of children who are sick or feeble. Hence the ritual appears to play on fears that a child might be taken immediately following birth and a changeling substituted. ${ }^{115}$ This would be a particular concern if the baby was still unbaptized as its immortal soul would be in danger. We know from other contemporary sources that new mothers took precautions to try to prevent this from happening.

Yet a child that was always hungry, crying, pining and never satisfied might well make a mother think that this could not possibly be the child to which she had given birth, but must instead be a "changeling". ${ }^{116}$ At her wits end she might hope to solve the problem by getting

\footnotetext{
111 Jacques Berlioz, "De l'homme aux pois au Saint Lévrier", p.40

112 Marlène Albert-Llorca, "Le saint lévrier. Guinefort, guérisseur d'enfants depuis le XIIIe siècle" (Paris: Flammarion, 1st edn. 1979; new edn. 2004), p.2.

${ }^{113}$ Schmitt, The Holy Greyhound, pp.18-19.

114 Poly, Guinefort et les faramans des Dombes, p.105.

115 Schmitt, The Holy Greyhound, p.74.

${ }^{116}$ For the supposed incessant hunger of changelings see Doulet, Quand les démons enlevaient les enfants, pp.55-64.
} 
rid of this "changeling" by abandoning it, by making it suffer so that its true parents, the "fauns" could reclaim it, and only returning to the site when her own child had been restored. ${ }^{117}$ Such instances of deliberate negligence, including domestic "accidents" on the part of mothers was condemned by the canonist Ivo of Chartres (c.1040-1115), ${ }^{118}$ while the canonist and bishop Burchard of Worms (c.950/65-1025) imposed a year of penitence on mothers who put their children "on the roof or in a hole" in the hope of ridding them of fever. ${ }^{119}$ Similarly the mothers of the Dombes may have hoped that if their sick child did not recover, its exposure would lead to death. So, changelings were a way in which a community could explain sickness and abnormality and dispose of the burden of raising a sick child, while at the same time allowing mothers to relieve their consciences and avoid feelings of guilt for the child's death. We should note that it is at this period that the practice of annual confession, first decreed as obligatory at the Fourth Lateran Council (1215) was encouraging the idea of individual conscience and guilt. $^{120}$

Stephen of Bourbon also relates another curious element to the story:

One woman also told me that she had just invoked the fauns and was withdrawing from the scene when she saw a wolf come out of the forest towards the baby. If maternal love had not made her feel pity and go back for him, the wolf, or as she put it, the devil in the shape of a wolf, would have devoured the baby. ${ }^{121}$

Just as the "fauns" appear as demons, so for the mother the wolf appears as the devil. In medieval miracle stories and hagiographies, the wolf, like the dog, is sometimes a saviour of

\footnotetext{
117 Schmitt, The Holy Greyhound, p.74.

118 Ivo de Chartres, Decretum, Part XV, cap. 159, PL 161, col. 893; Doulet, Quand les démons enlevaient les enfants, p.193.

${ }^{119}$ Burchard of Worms, Decretum, Liv. XIX, art. 174; Schmitt, The Holy Greyhound, p.73; Doulet, Quand les démons enlevaient les enfants, p.193.

${ }^{120}$ Schmitt, The Holy Greyhound, p.82. We should also note that Richard Firth Green argues that the idea of the changeling was associated with issues of legitimacy and that "it is surely no co-incidence that a serpent-killing dog should become the patron saint of fairy abductees", see Green, Elf Queens and Holy Friars, p.116.

${ }^{121}$ Stephen of Bourbon, "De Supersticione", p.327.
} 
children. ${ }^{122}$ Yet here, the wolf is depicted as an enemy of the child, ironic considering the cult had originally been established in veneration of a greyhound who had proved a loyal friend to a baby. A psychologist today might say the wolf represents the mother's own aggressive nature and wish to abandon her sickly child. Schmitt has suggested that, possibly, like the fire, the wolf is symbolic of the mother, who, having abandoned her child, is left alone and at the mercy of terrifying demonic forces. ${ }^{123}$

Stephen completes his narrative with a description of the end of the ritual:

When a mother returned to her child and found it still alive, she carried it out into the fast-flowing waters of a nearby river, called the Chalaronne <a tributary of the Sasnel>, and plunged it in nine times; if it came through without dying on the spot, or shortly afterwards, it had a very strong constitution. ${ }^{124}$

There is a faint reminder here of the medieval ritual of trial by fire or water which seems to have been commonly employed in communities before canon lawyers in the thirteenth century increasingly declared the process uncanonical and the papacy used the inquisition as a substitute for such populist procedures. ${ }^{125}$ Just as in the trial by water, if the woman floated she was a witch and if she sank she was not, or in the trial by fire if the hand healed she was guilty but if there were burns she was innocent, so here also we see the employment of an "all or nothing" logic; if the baby resists the cold of the river after no less than nine immersions, it is the woman's true child; if it cannot it is a sickly changeling. ${ }^{126}$ Thus we see again in this description of the cult the idea of a saint with the power to decide whether a child should live or die. ${ }^{127}$

\footnotetext{
${ }^{122}$ Poly, Guinefort et les faramans des Dombes, pp.103-28, passim.

${ }^{123}$ Schmitt, The Holy Greyhound, p.72.

${ }^{124}$ Stephen of Bourbon, "De Supersticione", p.327.

125 John W. Baldwin, "The Intellectual Preparation of the Canon of 1215 against Ordeals", Speculum 36/4 (1961), 613-636. I would also like to thank my MA student Mari-Liis Neubauer who discussed the development of trials by fire and water with me.

${ }^{126}$ Schmitt, The Holy Greyhound, p.81; Doulet, Quand les démons enlevaient les enfants, p.196.

${ }^{127}$ Larché Milon, "Du chien Guignefort aux saints Guinefort”, p.59.
} 
Furthermore, there seems to be a relationship between the ritual described by Stephen of Bourbon and the Catholic rite of baptism. ${ }^{128}$ Baptism, acting as a defence against the Devil, was believed to be a potent form of protection against changelings. ${ }^{129}$ It is striking that Stephen's description of the rite includes the symbolic elements of salt, fire and water which were also key symbols of baptism. Furthermore, the immersion nine times in the Chalaronne reminds us of the triple immersion of baptism multiplied by three. ${ }^{130}$ However, we do not know whether the infants in question had already been baptised. Possibly they had not and this was a heretical equivalent of baptism, rather like the Cathar initiation ceremony in the south of France described by Peter of les Vaux-de-Cernay (fl. circa 1215) in the Historia Albigensis which, in its use of ritual and words, aped the Catholic sacrament. ${ }^{131}$

Although at this time the duchy of Bourgogne was no longer a centre of Catharism, ${ }^{132}$ the Cathar heresy was well known to Stephen who wrote a catalogue of errors of the Albigensians, which the Dominican inquisitor Bernard Gui drew upon in his own Manual of the Inquisition. ${ }^{133}$ We know from his writing that Stephen of Bourbon denounced heresy in no uncertain terms. ${ }^{134}$ Yet it is more probable that these babies had been baptised since, although traditionally baptisms took place at the Easter Vigil, increasingly in the twelfth and thirteenth centuries they were conducted immediately after birth to prevent children dying unbaptized. ${ }^{135}$

\footnotetext{
${ }^{128}$ Doulet, Quand les démons enlevaient les enfants, p.77.

${ }^{129}$ Schmitt, The Holy Greyhound, p.81; Doulet, Quand les démons enlevaient les enfants, pp.123-37.

${ }^{130}$ Schmitt, The Holy Greyhound, p.81.

${ }^{131}$ Peter of les Vaux-de-Cernay, Historia Albigensis, ed. Paschal Guébin and Ernest Lyon, 3 vols (Paris: Librairie Ancienne Honoré Champion, 1926-1939), Vol. 1, pp.19-20. For an English translation see Peter of les Vaux-de-Cernay, The History of the Albigensian Crusade, trans. William A. and Mary D. Sibly (Woodbridge: The Boydell Press, 1998), pp.14-15.

132 Berlioz, "Introduction" to Stephen of Bourbon, "Tractatus de Diversis Materiis Praedicabilibus", ed. Berlioz (and Eichenlaub), p.XXVIII.

${ }^{133}$ Berlioz, "Introduction" to Stephen of Bourbon, "Tractatus de Diversis Materiis Praedicabilibus", ed. Berlioz (and Eichenlaub), p.XXVII.

${ }^{134}$ Berlioz, "De l'homme aux pois au Saint Lévrier", pp.38-9.

135 Schmitt, The Holy Greyhound, p.81.
} 
If so then it is more likely that the rite of substitution which Stephen describes was not meant to stand in place of baptism but rather, by replicating aspects of the baptismal rite, to reawaken its effects. ${ }^{136}$

What is clear is that at stake was not just an innocent healing right combined with the inappropriate veneration of a greyhound as a saint, but something much more sinister: the exposure of babies. Three decretals of two twelfth-century popes, Alexander III (1159-1181) and Lucius III (1181-1185) reveal that the medieval Church was unwavering in its condemnation of infanticide. ${ }^{137}$ Possibly Stephen believed that the ultimate aims of this practice of post-birth birth control was to kill sick, weak and unwanted children. Yet, although he was rigorous, unlike his contemporary, the inquisitor Robert le Bougre (fl. first half of the thirteenth century), he was not fanatical or cruel, but appears as acting here with prudence and relative kindness. ${ }^{138}$ That Stephen chose to shut the rite down, rather than imposing more severe penalties, suggests that he almost certainly did not regard the cult as ritual infanticide. ${ }^{139}$

${ }^{136}$ Schmitt, The Holy Greyhound, p.82; Doulet, Quand les démons enlevaient les enfants, p. 210 .

${ }^{137}$ Alexander III, "Vice beati Petri" (9 August 1171-2), Patrologia Cursus Completus, Series Latina, comp. Jacques Paul Migne (Paris: Apud J.-P. Migne, 1841-64), (henceforward PL) 200, no. 975, cols 849-52, at 850. See also the rulings Alexander III, "Veniens ad nos M." (11591160), "Liber extra decretalium", Corpus iuris canonici, ed. Emil Friedberg, Vol. 2 (Leipzig: B. Tauchnitz, 1881) (henceforward X), 5.10.1, p.792; see also in PL 200, col. 84; Lucius III, "Intelleximus ex litteris" (1181-1185), X.5.10.2, p.792; Lucius III, "De infantibus" X.5.10.3, p.793 (listed as Alexander III, "De infantibus" (1159-1181) in Regesta pontificum Romanorum ab condita ecclesia ad annum post Christum natum 1198, 2 vols, ed. Philip Jaffé (Graz: Akademische Druck, 1956), Vol. 2, no. 14201. See Anne Duggan, “Alexander ille meus: The Papacy of Alexander III", in Pope Alexander III (1159-81): the Art of Survival, ed. Anne Duggan and Peter Clarke (Farnham, Surrey: Ashgate, 2012), p.46; John Boswell, The Kindness of Strangers (London: Allen Lane, The Penguin Press, 1988), p.279. See also the sermons against female infanticide by twelfth-century Germans of Otto, Bishop of Bamberg, in Ebbonis Vita Ottonis Episcopi Babenbergensis, ed. Georg Heinrich Pertz, MGH SS 12 (Hannover: Impensis Bibliopolii Hahniani, 1856), 850-1; see also Herbord, Dialogus de vita Ottonis episcopi Bambergensis, ed. Rudolfo Kőpke in MGH SS 20 (Hannover: Impensis Bibliopolii Hahniani, 1868), p.733, p.741.

${ }^{138}$ Berlioz, "De l'homme aux pois au Saint Lévrier", pp.33-34; p.40.

${ }^{139}$ Schmitt, The Holy Greyhound, p.35; Berlioz, "De l'homme aux pois au Saint Lévrier", pp.39-40. 
Indeed it seem likely that the mothers of the Dombes believed that what they were engaged in was a life-saving rite for their children which in fact ended by killing the weakest of them. ${ }^{140}$ Or perhaps, desperate at having given birth to a child that was weak and sick, they justified to themselves that the rite was not ritual infanticide since the children who died were changelings, not human beings. ${ }^{141}$ What is clear is that Stephen of Bourbon's censure of the rite of St Guinefort in the Dombes was not just a ban on a non-orthodox cult, nor merely a statement that humans, not animals, could be saints, nor only a condemnation of magical and heretical practices - although it was all these things. It was also a condemnation by the papal inquisition of a healing cult which had got out of hand and had led to the death of infants.

\section{Bibliography}

\section{Primary Sources}

Alexander III, “Opera omnia”, Patrologia Cursus Completus, Series Latina, comp. Jacques Paul Migne (Paris: Apud J.-P. Migne, 1841-64), (abbreviated PL), Vol. 200.

A Medieval Garner. Human Documents from the Four Centuries Preceding the Reformation, ed. and trans. George Gordon Coulton (London, 1910).

Aristotle, De Anima, trans. Hugh Lawson-Tancred (London: Penguin Books, 1986).

Aristotle's De Anima in the Version of William of Moerbeke and the Commentary of St Thomas Aquinas, trans. Kenelm Foster and Silvester Humphries with an Intro. by Ivo Thomas (London: Routledge and Keegan Paul, 1951).

Caesarius of Heisterbach, The Dialogue on Miracles: Caesarius of Heisterbach (1220-1235), trans. Henry von E. Scott and Charles Cook Swinton Bland, with intro. by George Gordon Coulton (London: G. Routledge and Sons, 1929).

Les Registres de Gregoire IX, ed. L. Auvray, 4 vols, Bibliothèques des écoles françaises d'Athènes et de Rome ( $2^{\text {nd }}$ Series), (Paris: Boccard, 1890-1955), Vol. 1, pp.351-2.

"Liber Extra decretalium", Corpus iuris canonici, ed. Emil Friedberg, Vol. 2 (Leipzig:

B. Tauchnitz, 1881).

\footnotetext{
${ }^{140}$ Schmitt, The Holy Greyhound, p.82.

${ }^{141}$ Schmitt, The Holy Greyhound, p.82.
} 
Otto, Bishop of Bamberg, Ebo, Vita Ottonis, ed. Georg Heinrich Pertz, in MGH SS 12 (Hannover: Impensis Bibliopolii Hahniani, 1856); see also Herbord, Dialogus de vita Ottonis episcopi Bambergensis, ed. Rudolfo Kőpke in MGH SS 20 (Hannover: Impensis Bibliopolii Hahniani, 1868).

Peter of les Vaux-de-Cernay, Historia Albigensis, ed. Paschal Guébin and Ernest Lyon, 3 vols (Paris: Librairie Ancienne Honoré Champion, 1926-1939).

Peter of les Vaux-de-Cernay, The History of the Albigensian Crusade, trans. William A. and Mary D. Sibly (Woodbridge: The Boydell Press, 1998).

Regesta pontificum Romanorum, ed. Auguste Potthast, 2 vols, (Graz: Akademische Druck- u. Verlagsanstalt, 1957).

Vol. 1 (Berolini: Rudolphi de Decker, 1874); Vol. 2 (Berolini: Rudolphi de Decker, 1874).

Regesta pontificum Romanorum ab condita ecclesia ad annum post Christum natum 1198, 2 vols, ed. Philip Jaffé (Graz: Akademische Druck, 1956).

St Augustine, The City of God against the Pagans, ed. and trans. Robert W. Dyson (Cambridge, New York: Cambridge University Press, 1998).

Stephen of Bourbon (Etienne de Bourbon), "De Superticione" in "De septem donis Spiritus Sancti", or "Tractatus de Diversis Materiis Praedicalibus", in Anecdotes Historiques, Legends et Apologues Tires de Receuil inedit d'Etienne de Bourbon, ed. Albert Lecoy de La Marche (Paris: La Société de 1'Histoire de France, 1877), pp.314-29; the story of St Guinefort is at pp.325-8. For a translation see "De Superticione", Medieval Sourcebook, Fordham University (online), trans. Paul Halsall.

Stephen of Bourbon, “Tractatus de Diversis Materiis Praedicabilibus”, ed. Jacques Berlioz (and Jean-Luc Eichenlaub), (Turnhout, 2002), pp.XV-XLVII.

St Francis of Assisi. Writings and Early Biographies, $3^{\text {rd }}$ edn., ed. Marion A. Habig (London: S.P.C.K., 1979).

The Seven Sages of Rome (Midland Version), ed. Jill Whitelock (Oxford: Oxford University Press, 2005).

The "Summa Theologica" of St. Thomas Aquinas, Part 1. QQ. 75-119, trans. Fathers of the English Dominican Province (London: Burns Oates and Washbourne Ltd, 1912).

Thomas Aquinas, On Human Nature, ed. with Intro. by Thomas S. Hibbs (Indianapolis, Cambridge: Hackett, 1999).

\section{Secondary Literature}

Anderson, Katherine, Frederick, Jill A., Suydam, Mary, Robbins, Jacqueline E., Cadden, Joan, "Review: le moine et la sorcière [The Sorceress] by Paméla Berger; Annie Leibovici; 
Georges Reinhart; Suzanne Schiffman,", The American Historical Review, Vol. 94, No. 4 (Oct., 1989), 1037-1039.

Berlioz, Jacques, "Introduction" to Stephen of Bourbon, "Tractatus de Diversis Materiis Praedicabilibus", ed. Jacques Berlioz (and J-L Eichenlaub), (Turnhout, 2002), pp.XVLXXVII.

Baldwin, John, W., "The Intellectual Preparation of the Canon of 1215 against Ordeals", Speculum 36/4 (1961), 613-636.

Berger, Paméla; Leibovici Annie; Reinhart, Georges; Schiffman Suzanne, "Review: le moine et la sorcière [The Sorceress]", The American Historical Review, Vol. 94, No. 4 (Oct., 1989), 1037-1039.

Berlioz, Jacques, "De l'homme aux pois au Saint Lévrier: le dominicain Etienne de Bourbon (mort vers 1261) dans la Dombes", in Saint-Guignefort: Légende, Archéologie, Histoire (Châtillon-sur-Chalaronne: Association Saint Guignefort, 2005), pp.25-41.

Berlioz, Jacques, "Appendix", in "De l'homme aux pois au Saint Lévrier: le dominicain Etienne de Bourbon (mort vers 1261) dans la Dombes”, in Saint-Guignefort: Légende, Archéologie, Histoire (Châtillon-sur-Chalaronne: Association Saint Guignefort, 2005), pp.435.

Borlase, William Copeland, The Age of the Saints: a Monograph of Early Christianity in Cornwall with the Legends of the Cornish Saints, And an Introduction Illustrative of the Ethnology of the District, $2^{\text {nd }}$ ed. (Truro: j. Pollard, 1895), p.89.

Boswell, John, The Kindness of Strangers (London: Allen Lane, The Penguin Press, 1988).

Communautés du Sud. Contribution à̀ l'anthropologie des collectivités rurales occitanes, ed. Daniel Fabre and Jacques Lacroix (Paris, 1975), Vol. 1.

d'Avray, David, Rationalities in History: A Weberian Essay in Comparison (Cambridge: Cambridge University Press, 2010).

Doulet, Jean-Michel, Quand les démons enlevaient les enfants. Les changelins: étude d'une figure mythique (Paris, 2002).

Duggan, Anne, "Alexander ille meus: The Papacy of Alexander III", in Pope Alexander III (1159-81): the Art of Survival, ed. Peter Clarke and Anne J. Duggan (Farnham, Surrey: Ashgate, 2016), pp.13-49.

Fabre, Daniel and Lacroix, Jacques, "Pour une anthropologie des collectivités rurales occitanes", in Communautés du Sud. Contribution à̀ l'anthropologie des collectivités rurales occitanes, ed. Daniel Fabre and Jacques Lacroix (Paris, 1975), Vol. 1, pp.10-44.

Freed, John, The Friars and German Society in the Thirteenth Century (Cambridge, Mass: Medieval Academy of America, 1977). 
Goodman, Walter, "Review / Film; "Sorceress": A Medieval Parable", The New York Times (1988).

Green, Richard Firth, Elf Queens and Holy Friars: Fairy Beliefs and the Medieval Church (Philadelphia, Pennsylvania: University of Pennsylvania Press, 2016).

Guérard, Albert Leon, French Civilization from its Origins to the Close of the Middle Ages (Boston: Houston Mifflin, 1921).

Hamilton, Bernard, Religion in the Medieval West (London: Edward Arnold, 1986),

Hinnesbuch, William A., The History of the Dominican Order, Vol. 1, Origins and Growth to 1500 (Staten Island, N.Y.: Alba House, 1966).

Kittredge, George, Lyman, “Arthur and Golagan”, Studies and Notes in Philology and Literature, Vol. VIII (Cambridge, Mass.: Harvard University Press, 1903).

Knowles, David, The Religious Orders in England, Vol 1 (Cambridge: Cambridge University Press, 1948).

Lawrence, Clifford Hugh, Medieval Monasticism: Forms of Religious Life in Western Europe in the Middle Ages, $4^{\text {th }}$ edn (Oxon: Routledge, 2015).

Ladurie, Emmanuel le Roy, "La Domus a Montaillou et en Haute Ariège au XIVe Siècle", Communautés du Sud, ed. Fabre and Lacroix, Vol. 1, pp.166-220.

Ladurie, Emmanuel le Roy, Montaillou: Cathars and Catholics in a French Village, 12941324, trans. Barbara Bray (Harmondsworth: Penguin, 1984).

Linehan, Peter, The Ladies of Zamora (Manchester: Manchester University Press, 1997).

Maret, Jean-Louis, "Préface", in Saint-Guignefort: Légende, Archéologie, Histoire

(Châtillon-sur-Chalaronne: Association Saint Guignefort, 2005), p.3.

Marlène Albert-Llorca, "Le Saint Lévrier. Guinefort, Guérisseur d'Enfants Depuis le XIIIe Siècle" (Paris: Flammarion, 1sr edn. 1979; new edn. 2004), pp.1-3.

Milon, Larché, Carole, "Du chien Guignefort aux saints Guinefort", in Saint-Guignefort: Légende, Archéologie, Histoire (Châtillon-sur-Chalaronne: Association Saint Guignefort, 2005), pp.47-60.

Moorman, John, A History of the Franciscan Order from its Origins to 1517, Vol. 1 Origins and Growth to 1500 (Oxford, 1966).

Paul, Tessa, The Complete Illustrated Encyclopedia of Saints (London: Hermes House, 2009).

Poisson, Jean Michel, "Recherches archeologiques dans le bois de Saint-Guignefort", in Saint-Guignefort: Légende, Archéologie, Histoire (Châtillon-sur-Chalaronne: Association Saint Guignefort, 2005), pp.7-23. 
Poisson, Jean Michel (trans.), "Les septs sages de Rome”, in Saint-Guignefort: Légende, Archéologie, Histoire (Châtillon-sur-Chalaronne: Association Saint Guignefort, 2005), p.24.

Poly, Jean-Pierre, Guinefort et les faramans des Dombes. Un example d'anthropologie médiévale (Paris 69: Raison présente, 1984).

Resnick, Irven, "Good Dog / Bad Dog: Dogs in Medieval Religious Polemic”, Ennarratio 18 (2013), 70-84.

Saint Guignefort. Légende, Archéologie, Histoire (Châtillon-sur-Chalaronne: Association Saint Guignefort, 2005).

Salter, David, Holy and Noble Beasts: Encounters with Animals in Medieval Literature (Woodbridge: D.S. Brewer, 2001).

Schmitt, Jean-Claude (trans.), Etienne of Bourbon, Exemplum, in Saint-Guignefort: Légende, Archéologie, Histoire (Châtillon-sur-Chalaronne: Association Saint Guignefort, 2005), pp.45 .

Schmitt, Jean-Claude, "Post-Scriptum", in in Saint-Guignefort: Légende, Archéologie, Histoire (Châtillon-sur-Chalaronne: Association Saint Guignefort, 2005), pp.61-4.

Schmitt, Jean-Claude, The Holy Greyhound: Guinefort, Healer of Children since the Thirteenth Century, trans. Martin Thom (Cambridge, New York, Paris: Cambridge University Press; Editions de la Maison des Sciences de l'Homme, 1983).

Severance, Allen Dudley, "Beatification and Canonization with Special Reference to Historic Proof and the Proof of Miracles", American Society of Church History. Papers of the American Society of Church History 2:3 (New York, 1912), 43-62.

Stow, Kenneth, Jewish Dogs: An Image and Its Interpreters: Continuity in the CatholicJewish Encounter (Stanford, Calif., 2006). 